\title{
The complex interaction between human resources management, the labor market and employment relations in Brazil
}

\section{A complexa interação entre Gestão de Pessoas, Mercado de Trabalho e Relações de Trabalho no Brasil}

\author{
Marcus Vinicius Gonçalves da Cruz \\ Fundação João Pinheiro, Belo Horizonte - MG, Brazil \\ marcus.cruz@fjp.mg.gov.br \\ Amyra Moyzes Sarsur \\ Instituto de Sociologia, University of Porto, Portugal \\ asarsur@hotmail.com \\ Wilson Aparecido Costa de Amorim \\ Universidade de São Paulo, Faculdade de Economia, Administração e Contabilidade, São Paulo, SP - Brazil \\ wamorim@usp.br \\ André Luiz Fischer \\ Universidade de São Paulo, Faculdade de Economia, Administração e Contabilidade, São Paulo, SP - Brazil \\ afischer@usp.br \\ Michele Ruzon Kassem \\ Universidade de São Paulo, Faculdade de Economia, Administração e Contabilidade, São Paulo, SP - Brazil \\ michele.ruzon@gmail.com
}

\begin{abstract}
This article reports results of qualitative research that examines how the literature available of human resource management (HRM) addresses the new characteristics of employment in Brazil in the 2000-2015 period; with an aging population, a reduction in the share of young people and increased educational level of the workforce, a drop in the number of non-employed, higher income for workers and a high rate of turnover. In employment relations, the trade unions obtained real raises above inflation and strikes have returned. Through a panel of specialists and literature on human resources management in Brazil, the study reveals a distance between the subjects of labor market, employment relations and HRM. Two hypotheses could explain these findings: $(\mathrm{H} 1)$ labor relation and labor market issues are of little value to HRM; and (H2) HRM and employment relations are treated as different professional areas and fields of knowledge, and are poorly integrated in organizations.
\end{abstract}

Keywords: human resources management, HRM, labor market, employment relations.

\section{Resumo}

$\mathrm{O}$ artigo traz resultados de pesquisa qualitativa que analisa como a temática da gestão de recursos humanos (HRM) considera as novas características do trabalho no Brasil no período 2000-2015; com o envelhecimento populacional, redução da proporção de jovens e aumento da escolaridade na força de trabalho, queda na taxa de desocupação, melhoria do rendimento dos trabalhadores e elevada rotatividade. Nas relações de trabalho, os sindicatos conquistaram aumentos reais e as greves retornaram. Por meio de painel de especialistas e levantamento bibliográfico sobre gestão de pessoas no Brasil o estudo revela uma distância das temáticas do mercado de trabalho; relações de trabalho e HRM. Duas suposições poderiam explicar esses achados: (H1) as questões referentes às relações de trabalho e ao mercado de trabalho são pouco valorizadas pela HRM; e (H2) HRM e relações de trabalho são tratadas como áreas profissionais e de conhecimento separadas e pouco integradas nas organizações.

Palavras-chave: gestão de recursos humanos, GRH, mercado de trabalho, relações de trabalho.

\section{Introduction}

In the early 1990s, attempts to analyze the relationship between human resource management (HRM) and broader conditions of the political and economic environment in Brazil were marked by a distance between the different fields of knowledge that could address the issue. From a Business Administration perspective, labor was usually treated as just another input to be managed, and employment relations were considered as one of the variables to be controlled by companies. In economic terms, the subject of the labor market and employment relations, with the latter considered a consequence and subtopic of the former, were treated almost like an undesirable factor in the productive process. In short, available literature in the fields of organizational theory and economics was predominantly prescriptive.

A third theoretical approach to the issue originated in the field of Social Sciences. Based mostly on Marxist theory, its analytical approach on employment relations rarely considered the internal scope of organizations. Its authors prioritized the prospect of conflict, focusing the analysis on the political aspects 
of actions taken by the trade unions in protests against the government's wage policies, or in occasional clashes with companies.

Since the 1990s, the Brazilian society and economy have gone through a long transitional period, probably still in progress, which radically affecting human resources management within organizations, on the assumption that labor market analysis offers a privileged vantage point for any attempt to understand this process. The context indicates important changes underway in the Brazilian labor market, including demographic trends that point to a drop in the birth rate, increased life expectancy at birth, and the relative aging of the Brazilian population. These new conditions combined with aspects in the economic scenario, also led to a drop in the unemployment rate, an increase in the average income of workers and continued high rates of turnover. With regards to employment relations, there has been an increase in the bargaining power of workers, and even the return of consistent strikes in several economic sectors.

This perspective underscores the need for further reflection on the strategies, policies and practices declared and undertaken by Brazilian organizations in the field of human resources management. Thus, we have turned to a line of research that dates back to the 1990s (Barbosa, 2005; Carvalho Neto, 2012; Fischer \& Albuquerque, 2005; Fleury \& Fischer, 1992), and which has been reinforced recently in studies by Leite \& Salas (2014); Maia \& Menezes (2014); and Wood, Tonelli \& Cooke (2011). At different times, these studies observed major economic, social and institutional changes in the country, and their main concern was the distance that literature and research on human resources management established from the themes of employment relations. In short, external factors such as economic, social and union environments were barely considered in research, and even in prescriptive publications on human resources management. In general, these authors point to the need to bring HRM closer to its external conditions, as an alternative to make it less prescriptive, more analytical and adapted to the reality of Brazilian organizations.

Based on that premise, some concerns may be listed as a backdrop in the development of this study: to what extent does human resources management in Brazil consider its external environment conditions related to the labor market? To what degree does HRM in Brazil interact with institutional bodies in the Brazilian labor market, such as governments and their public policies, trade unions and other types of organizations? How much do personnel managers know about their external environment conditions?

The use of the constructs "human resources management models", "labor market structure" and "employment relations" considers the descriptive and analytical aspects of human resources management models and its relationships with the structural and circumstantial conditions of the Brazilian labor market, without losing sight of the significance of the employment relations perspective.

The purpose of this article is to analyze the interaction between such constructs, taking into account the dimensions of the labor market, the context of employment relations and its impact on the configuration of the human resources management models practiced in Brazil in the 2000-2015 period. Initially, a panel of experts was gathered in order to determine the main characteristics of these constructs in conceptual terms, followed by a literature review aimed at delineating the relationship between the subjects of employment relations, labor market and human resources management models practiced by companies in Brazil based on their declared strategies, policies and practices.

\section{Literature Review}

Brazilian society underwent major transformations at the institutional level between 1978 and 1992. Coming out of a dictatorship, it began its democratization process, adopted a new Constitution in 1988, and interrupted its pattern of growth marked by the significant participation of the government, protection of its domestic market and high inflation. The business environment faced mounting uncertainty due to economic instability and the constant change in rules caused by the introduction of new packages, a dangerous proximity to hyperinflation and, in the 1990s, an abrupt opening of the domestic market to foreign competition. Demand for workers weakened, while companies were forced to revise their production processes in an attempt to survive in the new economy. In labor, trade unions resurfaced starting in the late 1970s, strikes became commonplace and collective bargaining focused on wage issues. Starting in the early 1990s, the lower levels of job creation resulted in rising non-employment rates; at the same time, qualification requirements increased for employed individuals. Meanwhile, the unions' bargaining power shrank (Amorim, 2015; Maia \& Menezes, 2014).

Fleury and Fischer (1992) observed these transformations and found that the text produced by social scientists on employment relations issues and management policies rarely turned their attention to the internal processes of organizations. In general, the analyses were filtered by the political relationships involving workers, their unions and political parties. Some of the causes for this distance between social scientists and issues related to administration included the fact that the subject often suffered from a lack of prestige in scholarly circles, as well as its association with the control of human labor or the interest in not politicizing the academic discourse on relations of production. On the other hand, texts on Administration were in large part superficial and dealt with employment relations in normative and prescriptive terms, opting against a more comprehensive analytical vision. These texts were exclusively concerned with the functionality of social relations within the company, did not take into consideration the possibilities of conflict and favored instrumentalization in detriment of a critical view.

Fleury e Fischer (1992) analyzed the discussion surrounding the changes underway in the realm of employment relations and organizational policies adopted to manage them in Brazil at the time, and proposed establishing conceptual bridges to understand the wide range of events which, as they affected companies, crossed into employment relations and, by extension, into human resource management. Thus, employment relations have their origin in the social relations of production, which is a particular form of integration between 
social agents that occupy opposite and complementary positions in the production process (employees and employers). As such, the standards on employment relations are delineated by their interaction with political, economic and institutional variables, but are also associated with what organizations, within their internal structures, defined as human resources administration tasks. Organizational culture - in its capacity to create a sense of organizational identity and establish the rules for coexistence and domination among agents - appears as one of the most important elements of this theoretical framework.

Since then, a link has been established between organizational policies and, as their byproducts, human resources management policies, management systems and their external and internal constraints associated with the employment relationship. On the one hand, the analysis of the power relations implicit in employment relations gained a point of access into organizational life. On the other, attempts to improve the scope and effectiveness of human resources management could now rely on the possibility of a sharper perspective of their constraints associated with employment relations.

Barbosa (2005) points out that this study was decisive for Brazilian research in the field of business administration, as it opened the way to a research front on how human resources are managed in the country. The contextual analysis proved to be indispensable to a better understanding of the results of human resources policies on organizations and, of course, on workers in Brazil.

The national political and economic scenario took on new contours since then. Human resources management in Brazil has undergone several waves of innovation, usually with some delay in relation to the North American or European theoretical matrices. Total quality, outsourcing, management skills, strategic human resources management, organizational climate management and other concepts were, and still are, widely prescribed and applied. In all of them, the critical view on the results of implementing new policies and practices is made possible with the contextual vision that considers external and internal environmental factors, as emphasized by Wood et al. (2011).

In early 1990s, the Brazilian labor market was marked by the loss of dynamism in new job creation, which had been one of its main characteristics in the previous decades. That occurred due to the country's low economic growth during those years. In two of its key supply side indicators, the labor market recorded significantly high unemployment, as well as a decrease in real wage levels. On the side of demand for workers, companies increased their requirements for performance and qualification of their employees or potential candidates. Companies adopted strategies and practices for its human resources management which, given the low bargaining power of workers, allowed them to exercise greater power in determining hiring conditions. For companies, it was a period marked by business adversity and a constant search for adjustments and gains in productivity. In their attempts to adjust, companies engaged in varying degrees of practices such as outsourcing, total quality, automation, downsizing and others, and these, in turn, reflected in human resource management. However, at least in regards to labor, these adjustments were facilitated by an oversupply of workers. The term "employability" - widely disseminated during this period - attributed to workers the responsibility for their own employment status, based on their personal development or qualification. Of course, in a labor market characterized by low demand for workers, "employability" transferred to workers a difficult load to shoulder in their professional life. In the early 2000 s, in the wake of increasingly common adoption of competency-based management, this load acquired new contours in corporate discourse (Carrieri \& Sarsur, 2004).

In the mid-part of the decade, the labor market started an inflection process. Economic growth resumed and the business environment became more favorable. On the labor supply side, the change to the economic scenario led to a drop in the unemployment rate, recovery of real income and trade unions regaining a more active presence within corporate environments (Leite \& Salas, 2014). As a result, the HRM of organizations was faced with a new range of possible roles (Fleury \& Fleury, 2005).

Barbosa (2005) noted that the field of HRM was very busy with the emergence of new approaches, such as competency-based management, organizational learning, and knowledge management. However, the author detected a move away from the subject of employment relations in HRM analyses, along with a consequent loss of identity for the area within the academic and organizational settings. The fast changes underway in the world of employment affect HRM in an irreversible manner, although this phenomenon is not effectively incorporated in its analyses.

To Carvalho Neto (2012), the distance between employment relations and HRM is largely due to epistemological issues. In this line of thought, employment relations are associated with a macro perspective, while human resources management are seen under a micro standpoint, thus preventing the two from intersecting.

The theoretical distancing that occurred in Brazil in the early 1990 s seems to repeat itself when employment relations and HRM, and their ensuing connections, are again analyzed in the first few years of the 2010s. The declared adoption of competency-based skills was joined by other practices and structures such as corporate education and targeted strategic HR management, with the creation of positions such as internal consultants and shared services centers. In all of them, there is a certain self-sufficiency of organizations in their choices of HRM models. In that sense, Wood et al. (2011) analyze the characteristics of HRM during this period and detect the presence of typically American management discourse and a strongly prescriptive tone. In one example, the common use of the term "talent retention" to describe an HRM task reveals the remnants of a period in which the decision to keep the employee on its staff was almost entirely up to the organization. On the other hand, faced with a stronger labor market, one could observe the perplexity of managers who now found it difficult to retain professionals or, before that, in hiring more skilled workers.

Brewster (2007) points out that the HRM concept that originated in USA schools is based on an implicit assumption that it is 
scientific in nature. However, that does not guarantee a unitary vision of the field. On the one hand, he identifies an HRM model which he calls "Michigan", which proposes a link between an organization's business and human resources strategies. In this model, the organization's strategy determines the employee type, as well as their development and performance. The work resembles any other resource within the organization. This line of thought shows a clear proximity to the core concepts of Neoclassical Theory. The HRM model - known as "Harvard" distinguishes labor from all other resources within the organization. The workers' comprehension and commitment is a crucial element to the success of an organization's strategy.

According to Brewster (2007), authors from both schools believe that the scientific nature of HRM ensures that either of the models can bring results for organizations. Within the context of globalization, this would be evidenced by the dissemination of best practices by US multinationals, or as prescribed by consultants. As such, the HRM from the USA presents itself as universal.

When analyzing the HRM in Europe, Brewster (2007) points out that, while the continent is not homogeneous, its model still differs from that of the USA. Such differences can be identified from the cultural component of individualism - a phenomenon that is more pronounced in the USA than in Europe. A second distinguishing factor would be the role of the State guaranteeing a more active labor legislation in Europe than in the USA.

A third aspect would be the influence of trade unions and the level of participation of workers in labor issues - greater in Europe than in the USA. The fourth element would be ownership structure, which would apply less pressure for short-term profits in Europe, when compared to US companies. In his study, Brewster (2007) concluded that Europe has been faced with a deregulation trend in its labor market, with a view to providing more hiring flexibility. To some extent, this tendency could be linked to the very characteristic of the HRM practices in the USA model. However, the author believes that the some of the more typically European aspects still clearly differ from the USA labor market in terms of the institutional framework around labor, the greater presence of trade unions and greater likelihood of involving employee participation in the organization's management.

This article does not intend on furthering the study on the differences and similarities between the HRM models in the USA and Europe. The most immediate concern is to note that an initial step for a better understanding of HRM between different countries, or even of its evolution over time in a single country is the analysis of its most relevant external constraints. The research by Brewster (2003) seems particularly important in that sense, by electing the determining factors of Human Resources settings from a given social reality, namely: culture, the role of the State, the influence of trade unions, the ownership structure of companies and, of course, the labor market's behavior; which are also mentioned in the studies of Mayrhofer (2004), Mitchell (2001) and Parry, Stavrou-Costea and Morley (2011).

\section{Methodology}

In methodological terms, the research adopted a qualitative approach (May, 2004) of descriptive nature, as it sought to understand the characteristics of a particular population or phenomenon (Minayo, 2010) focused on the dimensions of the labor market, the context of employment relations and its impact on the configuration of the human resources management models practiced in Brazil in the 2000-2015 period.

By reviewing official documents from the Ministry of Labor and Employment (MTE, 2014) and the Brazilian Institute of Geography and Statistics (IBGE, 2015) that provided an overview of the labor market in Brazil, as well as documents from the Inter-Union Department of Statistics and Socioeconomic Studies (DIEESE, 2016) for the current dynamics in employment relationships, this study mapped out the Brazilian labor market according to data from six metropolitan regions in Brazil - São Paulo, Rio de Janeiro, Porto Alegre, Recife, Belo Horizonte and Salvador. The data obtained were the basis for presentation and a preliminary discussion with the expert panel used for purposes of the research.

The expert panel was assembled according to the Delphi Method, and was used to obtain a qualified collective opinion on specific issues, from a group of selected people (Piola, Vianna \& Vivas, 2001). This structured technique seeks to obtain a collegiate interaction process, which allows a group of individuals with knowledge on a particular subject to deal with complex problems. The panel was held in June 2015 at the University of São Paulo, for about four hours, and the information was fully recorded for later analysis. The participants invited were specialists with vast experience in HRM consultancy for companies and trade unions, as well as journalists who cover these subjects. The event featured 5 HRM managers, 1 trade union representative, 5 scholars and 4 members of the research group. Perception was used as a form of measurement, through the use of the aggregate opinion and judgment of a panel composed of highly qualified and experienced individuals, which constituted an independent group of experts and connoisseurs of the fields of labor market and employment relations and HRM professionals, thus blending professionals and scholars.

Based on literature review on HRM, labor market and employment relations in Brazil, the research used selective reading to explore such themes in the work of Lima and Mioto (2007), using studies such as that of Caldas and Tinoco (2004) as reference. In addition to determining these references, a documentary analysis was conducted with the purpose of increasing the understanding of the problems involved (Creswell, 2010), since the documents can be used to infer how the events are constructed, and how justifications are registered (May, 2004). In addition, it was also possible to access and analyze original documents that assisted in the description of the phenomenon studied (Sá-Silva; Almeida \& Guindani, 2009). A detailed description of the literature review procedures is provided in the following section, which presents the main results of such analysis. 


\section{Results}

Carvalho Neto (2012) conducts a comparative analysis of how the fields of human resource management (HRM) and employment relations are discussed in the literature and research in Brazil. In HRM, focus is predominantly at the micro level, while the macro approach prevails among employment relations scholars, with analyses focused on how different contexts determine the phenomena, whereas the HRM authors work with the notion of a conditioning context, but are not determinant of its actions. In some ways, there is an underlying idea that the organizations, and consequently its HRM area, have the capacity to control external environment conditions, including employment relations. Based on this idea, intervening factors such as labor market behavior and even the role of trade unions are only tangentially addressed in the proposed models, or even in research.

Among the earliest findings in the research activities with experts, as well as in the studies consulted, there is an emphasis on general difficulties faced by companies regarding the workforce. In labor market relations, there are complaints about the difficulty of hiring and retaining workers, as well as towards trade unions and their demands.

Especially in relation to the 2015 scenario, the experts believe that HR managers were caught by surprise or were unprepared for the speed with which the labor market was hit by the economic crisis. Based on their experience, the experts described many cases in which the HR manager or department was informed of a need for adjustments or layoffs. This surprise is evidenced by the increasing frequency at which strategic or even tactical reviews of HRM are conducted, in an attempt to keep up with the events.

According to the experts consulted, labor market institutions such as trade unions, government agencies involved in labor supervision, or even public employment agencies - external to the organization are mostly ignored by HR managers as a source of data or even as potential mediators on these issues. It is reasonable to assume that this could be the source of organizations' difficulty for engaging in dialogue, seen as the main role of these institutions is to represent the interests of workers or of the State itself.

The experts also suggested a number of issues that could be presented to participants in the next stages of research, which will be conducted with focus groups featuring HRM professionals from Brazil.

- How does HR and its professionals deal with medium-term issues (5 years) such as retention, development and career (strategic planning)?

- What motivates an HR department to devise a project? What projects is it interested in? What projects are HR departments working on? Which projects would be expendable? How does HR choose its projects?

\section{- What are the priorities of an HR department?}

- What is the role of HR regarding employment relations and employment relations?

- Where do HR professionals get their information? What are their sources? What is the level of complexity of this information?

Having obtained the experts' perspective, the study proceeded to further explore the following topics: (i) human resources management models (Brewster, Mayrhofer \& Reichel, 2011; Fischer \& Albuquerque, 2005; Itzhak, \& Meshoulam, 2010); (ii) labor market structure in Brazil (Leite \& Sala, 2014; Maia \& Menezes, 2014); and (iii) employment relations (Brewster, 2007; Fleury \& Fischer, 1992; Kaufman, 2010).

The lack of studies aimed at a theoretical convergence of these different fields reflects an approach that does not associate strategic HR management with issues that are relevant to managers, such as non-employment rates, turnover, the role of trade unions, strikes and negotiations. This void in the literature and even in research in Brazil had already detected back in the early 1990s (Fleury \& Fischer, 1992), and by subsequent (Barbosa, 2005; Fischer \& Albuquerque, 2005) and even more recent studies (Amorim, 2015; Cruz, Amorim \& Sarsur, 2012; Wood et al., 2011). Given the importance of these aspects to HRM, this study sought to assess, in Brazilian and international literature, what had been produced at the confluence of "human resources management", "labor market" and "employment relations".

The review of academic studies was aimed at finding works that establish a relationship between the three different subjects addressed in this research - "human resources management models", "labor market" and "employment relationships" at the Brazilian and international levels, as shown in Table 1.

Table 1 - Searched keywords and combinations

\begin{tabular}{|l|l|}
\hline \multicolumn{1}{|c|}{ Keywords } & \multicolumn{1}{c|}{ Combinations } \\
\hline Human Resources & Human Resources Management + Employment Relations \\
Employment Relations & Human Resources Management + Labor Market \\
Labor Market & Human Resources Management + Labor Market + Employment Relations \\
Strategic Human Resources & Human Resources Management Models + Labor Market \\
Human Resources Management & Human Resources Management Models + Employment Relations \\
Human Resources Management Models & Strategic Human Resources + Labor Market \\
& Strategic Human Resources + Employment Relations \\
& Human Resources + Employment Relations \\
& Human Resources + Labor Market \\
& Human Resources + Labor Market + Employment Relations \\
\hline
\end{tabular}

Source: Authors. 
For Brazilian studies, the research used search engines to consult electronic databases - SciELO (Scientific Library on Line), SPELL (Scientific Periodicals Electronic Library) and the journal portal CAPES (created by the Coordinating Body for Higher Education Personnel Improvement, CAPES), in addition to the website of the National Association of Graduate Studies and Research in Business Administration, as shown in Table 2. Authors such as Lima and Mioto (2007) reinforce the significance of these searches, since, in Brazil, the CAPES portal ranks Brazilian and international scientific journals according to categories that are distinguished by quality. Similarly, SciELO is aimed at disseminating scientific literature in the electronic format, while the SPELL gathers scientific production in the fields of Business Administration, Accounting and Tourism, and is composed of a repository of scientific articles, indexing system and a search engine and information system on journals and articles.

Table 2 - Portals searched (December 2014)

\begin{tabular}{|l|l|}
\hline \multicolumn{1}{|c|}{ Database/Portal } & \multicolumn{1}{c|}{ Type of search } \\
\hline CAPES Journals & $\begin{array}{l}\text { Advanced search, Reference "ANY; IS (EXACT)", Date of publication "any year", type of material } \\
\text { "articles", language "any" (unspecified date) }\end{array}$ \\
\hline $\begin{array}{l}\text { Scielo - Scientific Electronic } \\
\text { Library Online }\end{array}$ & $\begin{array}{l}\text { In Portuguese, under the "article" category, search type "search articles", search keywords in the } \\
\text { field "subject". }\end{array}$ \\
\hline $\begin{array}{l}\text { SPELL }{ }^{\circledR} \text { Scientific Periodicals } \\
\text { Electronic Library }\end{array}$ & In Portuguese, under advanced search, search type "keyword"; no other specifications. \\
\hline ANPAD & In Portuguese, under search, no other specifications. \\
\hline
\end{tabular}

Source: Authors

This search results in the preliminary delimitation of 122 works. In general, no studies were found that, through an analytical or even practical model, integrated the three themes proposed by this research - Human Resources Administration/Human Resources Management, Employment Relations, Labor Market. The compiled literature consists primarily of isolated studies on professionals and their career, with a lot of attention devoted to health-related aspects of these subjects.

In an attempt to refine the search process, the works found in the initial search were analyzed based on their title and keywords. After this stage, the total was reduced to 42 articles of potential interest, which were read and examined in detail, with 18 works remaining after this analysis.

Out of these 18 articles, one third were classified as theoretical essays and another third as literature review. There were also three qualitative studies, one quantitative study and two studies that employed both of these approaches. In terms of the actors involved, non-excluding, 16 works were about organizations, 12 were on individuals, nine on the labor market, five on the State and only three on unions. Regards the different areas or roles of HR discussed in the works, the most oft-cited subject found was personnel training (seven articles), evaluation, career and attraction (all with five jobs).

The data gathered indicate that the confluence of the themes sought by the research - Human Resources Administration/Human Resources Management; Employment Relations; Labor Market - continues to be little explored by research in the field, whether in conceptual or in practical terms. In short, there is little accumulated knowledge about how the different $H R$ areas and its professionals deal with the contextual aspects of this activity, or on how they reflect on these aspects.

Internationally, the search focused on articles published in the period of 2000 to 2016 in journals with an impact factor greater than or equal to 1.4 , identified through the search platforms Web of Knowledge and Sciencedirect, using as reference the translation of terms into English (Gestão de Pessoas: human resource, human resources; Relações de Trabalho: employment relation, employment relations; Mercado de Trabalho: labor market, labour market).

The first selection of articles was based on the citation of the three terms in their titles. However, no articles were found with all of these three terms. A search for articles that mentioned at least two of the terms on their titles also produced limited results. Only three articles contain the combinations "human resources management and labor market" or "human resources management and employment relations" in their titles, while the combination "employment relations and labor market" was not found on the title of any articles. Given these results, the search was expanded to articles that contained the combination of all three terms in their title, abstract or keywords, resulting in eight articles. After reading these articles, however, the conclusion was that, while all three terms were mentioned, they were not the central themes of the papers. Rather, the discussion was limited to the relationship between only two of these terms human resources and employment relations; human resources and the labor market; or employment relations and the labor market.

Due to the scarcity of published articles that mentioned all three terms, the search was expanded, considering the combined presence of at least two terms in the title, abstract or keywords. That criteria produced 141 articles, which were organized after an analysis of their main topics of discussions, as follows: 11 articles, despite mentioning the terms, focus on different topics; 51 articles focus predominantly on only one of the topics, without correlating the terms - of these, 20 articles describe the labor market; 19 articles discuss specific human resources management policies/practices; and 12 articles discuss the role of institutions on employment relations. It was found that 74 articles discuss two of these terms - of those, 34 articles examine how human resources management policies adapt to specific characteristics of a given labor market; 25 articles discuss the relationship between human resource management practices and labor relations; 15 articles discuss employment relations in light of the specific characteristics of a given labor market. Finally, six articles focus on the relationship human resources 
management, employment relations and the labor market. A brief analysis of these articles follows.

The difficulty of associating all three terms is discussed by Mitchell (2001) and by Delbridge, Hauptmeier and Sengupta (2011), who see a critical point in the opposition between the internal perspective of human resources management, that is, the focus on the organizational context, to the detriment of an external perspective adopted in discussions on labor relations (focus on economic, institutional and social issues, including labor market characteristics). Therefore, multilevel studies are limited, and the use of simplified models prevails, hindering the development of new theories. Ollo-Lopez, Bayo-Moriones and Larranza-Kintana (2011) try to break away from this scenario and propose a quantitative study that associates the definition of human resources management in new employment practices (adoption of autonomous teams, autonomy at work, job rotation, communication processes started by the employee) with three aspects that are external to the organization: national culture characteristics, characteristics of the national system of labor relations and characteristics of the national labor market, based on the country's level of economic development. The results indicate a relationship between employment practices and the national culture, as well as with employment relationship system, although economic development does not play a significant role - which, the authors alert that this last factor should be studied more closely.

Another approach to associate the concepts of human resources management, employment relations and labor market is the presentation of a study case focused on a country or an industry. Itzhak and Meshoulam (2010) describe the Israeli context, characterizing the labor market according to an analysis of the meaning of work (the authors show that the population has become more individualistic since the 1960s), and then discuss employment relations through the evolution of trade unions' representativeness in the country, and the still incipient trend towards making human resources management practices more strategic, from a historical perspective. Another example of a national case study is the research on Japan conducted by Hemmert and Waldenberger (2000), which differs from the Israeli study only in its approach towards the labor market, as it emphasizes demographic aspects (aging of the Japanese population) rather than the meaning of work, but maintaining a historical perspective on the subject. Finally, there is the study by Terry (2011) on the cruise ship industry, which clearly highlights the interrelation between the three dimensions: human resources management, employment relations and labor market, by analyzing an industry characterized by its high level of internationalization (access to several labor markets) and its low level of regulation of employment relations.

The results of this research confirm the knowledge gap on the confluence between Human Resources Management, the Labor Market and Employment Relations, as well as an opportunity to advance in this direction. Although they were not mentioned in the literature review described herein, Brewster (2007), Mayrhofer (2004) and Morley (2012) have made efforts to compare the structure of HR systems in several countries. In a general manner, these authors have sought to establish connections between the national contexts and the forms that human resources management has taken in various countries. The understanding of the influence of contextual elements on organizations joins a tradition of research focused on the institutional dimension - which includes labor legislation, national culture, labor market, trade union action, etc. - in which they are introduced (Amorim, 2015).

According to Kaufman (2010), in the field of Labor Relations, this approach is also at the heart of the theoretical framework of Industrial Relations system (IRS) of John T. Dunlop and other American authors. Kaufman (2010) indicates that this theoretical approach can be further developed to encompass the practices of organizations towards their employees. The author extends the IRS approach to the internal dimension of the organizations, developing concepts around what can be described as an Employment Relations System. He then establishes connections between the external and internal labor market of the organization, enabling the observation and analysis of its implications to human resources management. In this sense, by highlighting the contextual dimension that conditions the roles of the different HR areas, it is possible, at a conceptual level, to identify and analyze the elements of its external environment such as the labor market, or even employment relations. In the next section some brief reflections on research findings.

\section{Conclusion}

The purpose of this article was to analyze the relationships between human resource management, the labor market and employment relations within the Brazilian context. The initial step consisted of an expert panel and a literature review about Brazilian and international studies on these themes. As a result, it was concluded that, in Brazil, despite the theoretical essays that address the need for this type of research since the early 1990s, researchers have failed to respond to such an appeal, and studies along these lines are rare or even non-existent.

On the other hand, data on the Brazilian labor market show that significant changes have taken place in the first 15 years of this century, contrasting against a previous scenario of relative comfort for employers in the labor market. In face of these changes, it would be reasonable to assume that Human Resources managers felt pressured to seek information to guide their strategies towards the labor market and trade union negotiations. As noted in the expert panel and documentary analysis, HR professionals took practical initiatives to deal with the shortage of workforce, joining forces within a given industry or geographical area, in an attempt to create balance mechanisms through agreements between organizations that created common parameters to deal with a demanding market.

Two hypotheses could explain these findings. A first hypothesis suggests that employment relations and labor market issues are little valued by HRM, since most of the discussions related to these issues are held by the legal departments of organizations, due to the strict structure of labor regulations in Brazil, monitored by the State. Another hypothesis is that HRM and employment relations are treated as different professional areas and fields of knowledge, and are poorly integrated in organizations - one is focused on the dynamics related to the daily routine of human resources 
management, centered around functional units responsible for operational activities such as recruitment, selection and careers, for example; while the other involves the areas responsible for dealing with the trade unions and their representatives, in an effort to remain compliant with the labor agreements.

From among the main theoretical and practical implications presented in the article, we draw attention to the need to develop a larger body of research involving the themes associated with human resource management, the labor market and employment relations within the Brazilian context. The thematic complexity also observed in the assessment of international studies confirms the relevance of this study, which offers, as practical implications, the need for better training of HRM professionals and greater dissemination of concepts in the field, critical to organizations. One of the study's main limitations is the need to expand the literature review to other available databases, as well as to perform a robust quantitative analysis on the themes under study.

\section{Acknowledgements}

The authors thank FAPEMIG and FAPESP for their financial support.

\section{References}

Amorim, W.A.C. (2015). Negociações coletivas no Brasil. São Paulo: Atlas. Barbosa, A.C.Q. (2005) Relações de trabalho e recursos humanos. Revista de Administração de Empresas, 45(1), 121-126.

Brewster, C. (2007) Comparative HRM: European views and perspectives. International Journal of Human Resource Management, 18(5), 769-787.

Brewster, C., Mayrhofer, W. \& Reichel, A. (2011). Riding the tiger? Going along with Cranet for two decades: a relational perspective. Human Resource Management Review, 21, 5-15.

Caldas, M. \& Tinoco, T. (2004). Pesquisa em gestão de recursos humanos nos anos 1990: um estudo bibliométrico. Revista de Administração de Empresas, 44(3), 100-114.

Carrieri, A.P., \& Sarsur, A. M. (2004). Percurso semântico do tema empregabilidade: a (re)construção de parte da história de uma empresa de telefonia. Revista de Administração Contemporânea, $8(1), 129-150$

Carvalho Neto, A. (2012). Relações de Trabalho e Gestão de Pessoas: entre o macro e o micro? Provocações epistemológicas. REGE. Revista de Gestão USP, 19, 297-306.

Creswell, J.W. (2010). Projeto de Pesquisa. Porto Alegre: Artmed.

Cruz, M.V.G.; Sarsur, A.M. \& Amorim, W.A.C. (2012). Gestão de competências nas relações de trabalho: o que pensam os sindicalistas? Revista de Administração Contemporânea, 16(5), 705-722.

Delbridge, R.; Hauptmeier, M. \& Sengupta, S. (2011). Beyond the enterprise: broadening the horizons of International HRM. Human Relations, 64(4), 483-505.

DIEESE. (2016). Balanço das negociações dos reajustes salariais de 2015. Estudos e Pesquisas, 80.

Fischer, A.L. \& Albuqueque, L.G. (2005). Trends of the human resources management model in Brazilian companies: a forecast according to opinion leaders from the area. The International Journal of Human Resource Management, 16(7), 1211-1227.

Fleury, M.T.L. \& Fischer, R.M. (1992). Relações de trabalho e políticas de gestão: uma história das questões atuais. Revista de Administração USP, 27, 5-15.

Fleury, M.T.L. \& Fleury, A.C.C. (2005). In search of competence: aligning strategy and competences in the telecommunications industry. International Journal of Human Resource Management, 16 (9), 1640-1655.
Hemmert, D.D.M. \& Waldenberger, J.L.H.M. (2000). The Japanese employment system in transition. International Business Review, 9(5), 525-553.

IBGE. (2015). Pesquisa Mensal de Emprego. Principais destaques da evolução do Mercado de trabalho nas regiões metropolitanas abrangidas pela pesquisa. Indicadores IBGE. Rio de Janeiro: IBGE.

Itzhak, H. \& Meshoulam, I. (2010). The meaning of work, employment relations and strategic human resources management in Israel. Human Resource Management Review, 20(3), 212-223.

Kaufman, B.E. (2010). The theoretical foundation of industrial relations and its implications for labor economics and human resource management. Industrial and Labor Relations Review, 64(1), 74-107.

Leite, M.P. \& Salas, C. (2014). Trabalho e desigualdades sob um novo modelo de desenvolvimento. Tempo Social, 26(1), 87-100.

Lima, T. C., \& Mioto, R. C. T. (2007). Procedimentos metodológicos na construção do conhecimento científico: a pesquisa bibliográfica. Revista Katálysis, 10(2), 37-45.

Maia, A. G., \& Menezes, E. (2014). Economic growth, labor and productivity in Brazil and the United States: a comparative analysis. Revista de Economia Política, 34(2), 212-229.

May, T. (2004). Pesquisa social: questões, métodos e processos. Porto Alegre: Artmed.

Mayrhofer, W. et al. (2004). Convergence, stasis or divergence? In: C. Brewster et al. (Eds.). Human Resource Management in Europe. Evidence of Convergence? London: Elsevier ButterworthHeinemann.

Minayo, M.C.S. (2010). Los conceptos estructurantes de la investigación cualitativa. Salud Colectiva, 6(3), 251-261.

Mitchell, D.J.B. (2001). IR journal and conference literature from the 1960s to the 1990s: what can HR lean from it? Where is it headed? Human Resource Management Review, 11(4), 375-393.

Morley, M. J. et al. (2012). The transition states of Central and Eastern Europe and the Former Soviet Union. In: C. Brester, \& W. Mayrhofer (Orgs.). Handbook of research on comparative human resource management. Cheltenham: Edward Elgar Publishing.

MTE. (2014). CAGED/RAIS. PDET - Programa e Disseminação de Estatísticas do Trabalho. Ministério do Emprego e do Trabalho.

Ollo-Lopez, A.; Bayo-Moriones, A. \& Larranza-Kintana, M. (2011). The impact of country level factors on the use of new work practices. Journal of World Business, 46(3), 394-403.

Parry, E., Stavrou-Costea, E. \& Morley, M.J. (2011). The Cranet International Research Network on Human Resource Management in retrospect and prospect. Human Resource Management Review, 21, 1-4.

Piola, S.F., Vianna, S.M., \& Vivas-Consuelo, D. (2002). Estudo Delphi: atores sociais e tendências do sistema de saúde brasileiro. Cadernos de Saúde Pública, 18(Suppl.), S181-S190.

Sá-Silva, J.R., Almeida, C.D. \& Guindani, J.F. (2009). Pesquisa documental: pistas teóricas e metodológicas. Revista Brasileira de História e Ciências Sociais, 1(1), 11-25.

Terry, W.C. (2011). Geographic limits to global labor market flexibility: the human resources paradox of the cruise industry. Geoforum, 42(6), 660-670.

Wood Jr., T., Tonelli, M. J. \& Cooke, B. (2011). Colonização e neocolonização da gestão de recursos humanos no Brasil (19502010). Revista de Administração de Empresas, 51(3), 232-243.

Received: 14 August 2016

Revisions required: 15 January 2017

Accepted: 23 April 2017 